\title{
Prostatic Muscular Tissue
}

National Cancer Institute

\section{Source}

National Cancer Institute. Prostatic Muscular Tissue. NCI Thesaurus. Code C13100.

The supporting structure for the prostate. A dense layer of smooth muscle tissue lies directly underneath the fibrous capsule and another dense layer of circular fibers surrounds the urethra (striated and smooth). In between these two layers is a mesh of smooth muscle tissue in which the prostatic glands are embedded. 